\title{
FAKTOR- FAKTOR YANG BERHUBUNGAN DENGAN KEJADIAN ANEMIA PADA IBU HAMIL DI PUSKESMAS BUKIT SANGKAL PALEMBANG TAHUN 2019
}

\author{
Yuliska Putri', Vera Yuanita ${ }^{2}$ \\ Prodi DIII Kebidanan STIKES Mitra Adiguna Palembang \\ Komplek Kenten Permai Blok J No. 9-12 Kelurahan Bukit Sangkal Palembang \\ Email: v.yuanita@gmail.com
}

\begin{abstract}
Abstrak
Menurut WHO, prevalensi anemia pada ibu hamil di seluruh dunia adalah 41,8\%. Sel darah merah (eritrosit) di dalam tubuh dalam jumlah sedikit dosebut anemia.Banyak faktor yang mempengaruhi terjadinya anemia kehamilan di antaranya umur kehamilan, pendidikan ibu, pendapatan keluarga, jarak kehamilan, paritas. Ingin mengetahui Faktor-faktor yang berhubungan dengan kejadian anemia pad ibu hamil di Puskesmas Bukit Sangkal Palembang tahun 2019. Dalam penelitian ini populasi yang diambil adalah semua ibu hamil yang melakukan ANC di puskesmas Bukit Sangkat Palembang dengan jumlah sampel sebanyak 30 responden. Hasil penelitian didapatkan distribusi frekuensi responden sebagian besar tidak mengalami anemia sebanyak 18 responden (60\%). Ada hubungan antara usia kehamilan ( $p$ value $=0,021)$, paritas ( $p$ value $=0,030)$ dan jarak kehamilan $(p$ value $=0,009)$ dengan kejadian anemia pada ibu hamil di Puskesmas Bukit Sangkal Palembang tahun 2019. Saran diharapkan petugas kesehatan khususnya di Puskesmas Bukit Sangkal Palembang agar dapat meningkatkan penyuluhan dengan mengembangkan program KIE dan Konseling mengenai usia ibu danparitas ibu yang merupakan faktor resiko tinggi kejadian anemia pada ibu hamil khusnya ibu hamil trimester III.
\end{abstract}

Kata Kunci $\quad$ : Anemia, usia kehamilan, paritas, jarak kehamilan.

\begin{abstract}
According to WHO, the prevalence of anemia in pregnant women worldwide is $41.8 \%$. Red blood cells (erythrocytes) in the body in a small amount dosebut anemia.Many factors that influence the occurrence of pregnancy anemia include gestational age, maternal education, family income, pregnancy distance, parity. Want to know the factors related to the incidence of anemia in pregnant women at the Bukit Sangkal Palembang Health Center in 2019. In this study the population taken was all pregnant women who did ANC at the Bukit Sangkat Health Center in Palembang with a total sample of 30 respondents. The results showed the frequency distribution of respondents mostly did not experience anemia as much as 18 respondents (60\%). There is a relationship between gestational age ( $p$ value = $0.021)$, parity $(p$ value $=0.030)$ and pregnancy distance $(p$ value $=0.009)$ with the incidence of anemia in pregnant women at Bukit Sangkal Puskesmas Palembang in 2019. Suggestions for health workers, especially at Bukit Puskesmas Sangkal Palembang in order to improve counseling by developing IEC and counseling programs regarding maternal age and maternal parity which are high risk factors for anemia in pregnant women especially in third trimester pregnant women.
\end{abstract}

Keywords : Anemia, gestational age, parity, distance of pregnancy 


\section{PENDAHULUAN}

Anemia adalah salah satu masalah kesehatan global yang umum dan tersebar luas serta memengaruhi 56 juta wanita di seluruh dunia, dan dua pertiga di antaranya berada di Asia (Soh et al, 2015). Di negara berkembang, anemia menjadi perhatian yang serius karena dampaknya pada ibu maupun janin berkontribusi terhadap kematian maternal (Sharma and Meenakshi, 2010).Anemia pada wanita usia subur menjadi perhatian World Health Organization dan ditargetkan dapat direduksi sebanyak 50\% pada tahun 2015.

Menurut WHO, prevalensi anemia pada ibu hamil di seluruh dunia adalah $41,8 \%$. Sel darah merah (eritrosit) di dalam tubuh dalam jumlah sedikit dosebut anemia. Di Indonesia berdasarkan hasil Reskesdas tahun 2013, prevalensi anemia pada ibu hamil sebesar $37,1 \%$.pemerintah sudah menjalankan program penaggulangan anemia pada ibu hamil denganm pemberia 90 tablet Fe selama periode kehamilan untuk menurunkan anemia, (Kemenkes dalam Astriana, 2017).

Di Indonesia, kejadian anemia pada ibu hamil masih tinggi. Menurut data Riskesdas tahun 2013 jumlah ibu hamil yang mengalami anemia 37,1\% dan meningkat pada tahun 2018 menjadi 48,9\%, Anemia pada ibu hamil berdasarkan umur 15-24 tahun berjumlah 84,6\%, umur 25-34 tahun berjumlah 33,7\%, umur 36-44 tahun berjumlah $33,6 \%$ dan umur 45-54 tahun berjumlah 28\% (Riskesdas, 21018). Kelompok ibu hamil merupakan salah satu kelompok yang berisiko tinggi mengalami anemia.Anemia pada ibu hamil umumnya merupakan anemia relatif akibat perubahan fisiologis tubuh selama kehamilan yaitu adanya hemodilusi (Huang et al, 2015).

Berdasarkan data dari Dinas Kesehatan Kota Palembang tahun 2015 jumlah ibu yang berisiko anemia sebesar $97,97 \%$ orang. Tahun 2016 jumlah ibu hamil yang berisiko anemia sebesar 96,06\% orang. (Dinkes Palembang,2016).

Ibu hamil dapat mengalami anemia karena kebutuhan zat besi selama hamil meningkat untuk pertumbuhan janin.Anemia kehamilan dapat dicegah apabila seorang ibu mempunyai asupan nutrisi yang bagus sebelum hamil sehingga mempunyai cadangan zat besi di dalam tubuh (Noran and Mohammed, 2015).
Anemia dalam kehamilan dapat berdampak buruk terhadap mortalitas dan morbiditas ibu maupun janin.Hasil dari kehamilan dengan anemia di antaranya intra uterine growth retardation (IUGR), lahir prematur, berat bayi lahir rendah (BBLR), dan peningkatan risiko kematian neonatus. Efek anemia kehamilan pada ibu di antaranya sesak nafas, kelelahan, palpitasi, gangguan tidur, meningkatkan risiko pendarahan saat persalinan, preeklamsia, dan sepsis (Noran and Mohammed , 2015; Sharma and Meenakshi, 2010). Dampak buruk anemia kehamilan pada janin di negara berkembang lebih tinggi, sedangkan di negara industri prognosis perinatal tidak berhubungan dengan anemia kehamilan (Kozuma, 2009).

Banyak faktor yang mempengaruhi terjadinya anemia kehamilan di antaranya umur kehamilan, pendidikan ibu, pendapatan keluarga, jarak kehamilan, paritas, konsumsi tablet tambah darah (TTD), dan riwayat penyakit.Anemia di trimester (TM) I dan II tidak berhubungan dengan kejadian BBLR dan lahir preterm, sedangkan anemia di TM III mempunyai pengaruh terhadap kejadian BBLR dan lahir preterm (Huang et al, 2015).Tingkat pendidikan ibu berpengaruh terhadap anemia karena ibu yang berpendidikan tinggi dapat lebih memperhatikan kesehatannya dan janin yang dikandungnya (Soh et al, 2015).Pendapatan keluarga yang rendah memungkinkan ibu mendapatkan nutrisi yang kurang baik selama kehamilan sehingga risiko menderita anemia meningkat (Milman, 2013; Soh et al, 2015; Vehraet al, 2012). Interval kehamilan yang pendek mempunyai efek merugikan terhadap kadar hemoglobin (Vehra et al, 2012). Ibu hamil yang tidak mengonsumsi tablet tambah darah lebih berisiko mengalami anemia, selain itu riwayat penyakit seperti malaria dan cacingan juga dapat menyebabkan anemia (Alene and Abdulahi, 2014).

Dalam laporan Puskesmas tahun 2016 kejadian anemia di Puskesmas Bukit Sangkal pada tahun 2016 berjumlah 587\% ibu hamil dan ibu hamil yang mengalami anemia berjumlah 48\% ibu hamil, tahun 2017 berjumlah 542\% ibu hamil dan ibu hamil yang mengalami anemia berjumlah 45\% ibu hamil, dan tahun 2018 berjumlah $536 \%$ dan ibu hamil yang mengalami anemia berjumlah 39\% ibu hamil.

Di Puskesmas Bukit Sangkal, salah satu 
upaya untuk mengatasi anemia adalah dengan pemberian tablet tambah darah dan pemeriksaan kadar hemoglobin pada awal kunjungan antenatal care (ANC) serta pemeriksaan kadar hemoglobin minimal 1 kali setiap trimester sehingga kasus anemia akan cepat terdeteksi dan dapat segera dilakukan intervensi. Upaya ini belum dapat menurunkan angka kejadian anemia kehamilan karena banyak faktor yang memengaruhi terjadinya anemia.

Berdasarkan fakta di atas, peneliti mengambil judul penelitian tentang faktorfaktor yang berhubungan dengan kejadian anemia pada ibu hamil di Puskesmas Bukit Sangkal Palembang tahun 2019.

\section{METODE PENELITIAN}

\section{Ruang Lingkup}

Penelitian akan dilakukan pada semua ibu hamil untuk mengetahui faktor- faktor yang berhubungan dengan kejadian anemia pada ibu hamil di Puskesmas Bukit Sangkal Palembang 2019.

\section{Format Penelitian}

Didalam penelitian dikenal dengan berbagai macam metode dan pendekatan yang digunakan. Namun pada penelitian ini peneliti menggunakan metode analitik dengan pendekatan cross sectional.

\section{Waktu Penelitian}

Penelitian ini dilaksanakan pada tanggal 02-27 April 2019

\section{Tempat Penelitian}

Penelitian dilakukan di Puskesmas Bukit Sangkal Palembang 2019.

\section{Data dan Cara Pengumpulan Data Data}

\section{Data Primer}

Pada penelitian ini data yang digunakan adalah data primer yang diperoleh secara langsung dengan cara memberikan pertanyaan dalam bentuk kuesioner kepada semua ibu hamil untuk mengetahui faktor- faktor yang berhubungan dengan kejadian anemia

\section{Data Sekunder}

Dalam penelitian ini data sekunder didapat dari data ibu hamil di Puskesmas Bukit Sangkal Palembang.Jumlah ibu hamil diperoleh dari rekam medis.

\section{Teknik / Cara Pengumpulan Data}

Teknik pengumpulan data dalam penelitian ini peneliti menggunakan kuesioner sebagai alat dalam pengambilan data.

\section{Populasi dan Sampel Populasi}

Dalam penelitian ini populasi yang diambil adalah semua ibu hamil yang melakukan ANC di puskesmas Bukit Sangkat Palembang. Sampel

Sampel penelitian ini adalah sebagian ibu hamil trimester II dan trimester III yang melakukan ANC di Puskesmas Bukit Sangkal Palembang 2019.

\section{Teknik Pengambilan sampel}

Pengambilan sampel dalam penelitian ini dilakukan dengan cara non probability sampling menggunakan metode accidental sampling

\section{Teknik Analisis Data}

Analisa Data Univariat

Analisa univariat dilakukan terhadap tiap variabel dari hasil penelitian yaitu variabel independen (umur kehamilan, paritas, dan jarak kehamilan) dan variabel dependen (kejadian anemia pada ibu hamil) yang dianalisisdengan menggunakan tabel distribusi frekuensi.

\section{Analisa Bivariat}

Analisa ini dilakukan untuk mengetahui hubungan atau keterkaitan antara dua variable yaitu antara variabel bebas (umur kehamilan,paritas, jarak kehamilan dan variabel terikat (anemia pada ibu hamil), dengan menghitung ratio prevalence (umur kehamilan, paritas dan jarak kehamilan). Untuk mengetahui kemaknaan dilakukan uji chi-square dengan tingkat kepercayaan $95 \%(\alpha=0,05)$.

\section{HASIL PENELITIAN DAN PEMBAHASAN Hasil Penelitian \\ Analisis Univariat}

\section{Kejadian Anemia Pada Ibu Hamil Trimester II dan Trimester III}

Tabel 1. Distribusi Frekuensi BerdasarkanKejadian Anemia Pada Ibu Hamil Di Puskesmas Bukit Sangkal Palembang Tahun 2019

$\begin{array}{cccc}\text { No } & \begin{array}{c}\text { Kejadian Anemia Pada } \\ \text { Ibu }\end{array} & \text { Frekuensi } & \%\end{array}$




\begin{tabular}{rlcc}
\hline 1. & Anemia & 12 & 40 \\
2. & Tidak Anemia & 18 & 60 \\
\hline & Total & 30 & 100 \\
\hline
\end{tabular}

Dari tabel 1. diatas diketahui bahwa distribusi frekuensi responden sebagian besar tidak mengalami anemia sebanyak 18 responden $(60 \%)$ dan hanya 12 responden $(40 \%)$ yang mengalami anemia.

\section{Usia Kehamilan}

Tabel 2. Distribusi Frekuensi Berdasarkan Usia Kehamilan Ibu Hamil Di Puskesmas Bukit Sangkal Palembang Tahun 2019

\begin{tabular}{cccc}
\hline No & Usia Kehamilan & Frekuensi & \% \\
\hline 1. & $>28$ minggu & 16 & 53,3 \\
2. & $>13$ minggu & 14 & 46,7 \\
\hline & Total & 30 & 100 \\
\hline
\end{tabular}

Dari tabel 2. diatas diketahui bahwa distribusi frekuensi sebagian besar responden hamil trimester III sebanyak 16 responden $(53,3 \%)$ dan hanya 14 responden $(46,7 \%)$ yang hamil trimester II.

\section{Paritas Ibu}

Tabel 3. Distribusi Frekuensi BerdasarkanParitas Ibu Hamil Di Puskesmas Bukit Sangkal Palembang Tahun 2019

\begin{tabular}{cccc}
\hline No & Paritas Ibu & Frekuensi & \% \\
\hline 1. & Tinggi & 14 & 46,7 \\
2. & Rendah & 16 & 53,3 \\
\hline & Total & 30 & 100
\end{tabular}

Dari tabel 3. diatas diketahui bahwa distribusi frekuensi sebagian besar responden memiliki paritas resiko rendah sebanyak 16 responden $(53,3 \%)$ dan hanya 14 responden $(46,7 \%)$ yang memiliki paritas resiko tinggi.

\section{Jarak Kehamilan}

Tabel 4. Distribusi Frekuensi Berdasarkan Jarak Kehamilan Di Puskesmas Bukit Sangkal Palembang Tahun 2019

\begin{tabular}{clcc}
\hline No & Jarak Kehamilan & Frekuensi & \% \\
\hline 1. & Tinggi & 11 & 36,7 \\
2. & Rendah & 19 & 63,3 \\
\hline \multicolumn{2}{r}{ Total } & 30 & 100 \\
\hline
\end{tabular}

Dari tabel 4. diatas diketahui bahwa distribusi frekuensi sebagian besar responden memiliki jarak kehamilan resiko rendah sebanyak 19 responden $(63,3 \%)$ dan hanya 11 responden (36,7\%) yang memiliki jarak kehamilan resiko tinggi. 


\section{Analisis Bivariat}

\section{Hubungan Antara Usia Kehamilan Dengan Kejadian Anemia Pada Ibu Hamil}

Tabel 5.

Hubungan Antara Usia Kehamilan Dengan Kejadian Anemia Pada Ibu Hamil Di Puskesmas Bukit Sangkal Palembang Tahun 2019

\begin{tabular}{|c|c|c|c|c|c|c|c|c|c|}
\hline \multirow[t]{3}{*}{ No } & \multirow[t]{3}{*}{ Usia Kehamilan } & \multicolumn{4}{|c|}{$\begin{array}{c}\text { Kejadian Anemia Pada } \\
\text { Ibu Hamil } \\
\end{array}$} & \multicolumn{2}{|c|}{ Jumlah } & \multirow[t]{3}{*}{$p$ value } & \multirow{3}{*}{ OR } \\
\hline & & \multicolumn{2}{|c|}{$\mathbf{Y a}$} & \multicolumn{2}{|c|}{ Tidak } & \multirow[b]{2}{*}{$\mathbf{N}$} & \multirow[b]{2}{*}{$\%$} & & \\
\hline & & $\mathbf{n}$ & $\%$ & n & $\%$ & & & & \\
\hline 1. & 28-40 minggu & 10 & 62,5 & 6 & 37,5 & 16 & 100 & \multirow{3}{*}{0,021} & \multirow{3}{*}{10,000} \\
\hline 2. & 13-27 minggu & 2 & 14,3 & 12 & 85,7 & 14 & 100 & & \\
\hline & Jumlah & 12 & & 18 & & 30 & & & \\
\hline
\end{tabular}

Berdasarkan tabel 5. diatas dapat dilihat bahwa dari 16 responden usia kehamilan 28-40 minggu sebagian besar mengalami kejadian anemia sebanyak 10 responden $(62,5 \%)$, sedangkan dari 14 responden usia kehamilan 1327 minggu sebagian besar tidak mengalami anemia sebanyak 12 responden $(85,7 \%)$

Dari hasil uji Chi-Square didapatkan nilai $p$ value $0,021<\alpha(0,05)$ hal ini menunjukkan ada hubungan antara usia kehamilan dengan kejadian anemia pada ibu hamil di Puskesmas Bukit Sangkal Palembang tahun 2019.

Sedangkan nilai $\mathrm{OR}=10$ hal ini menunjukkan bahwa ibu hamil dengan usia kehamilan trimester III berpeluang mengalami kejadian anemia sebesar 10 kali dibandingkan dengan ibu hamil usia kehamilan trimester II.

Sehingga hipotesa awal yang menyatakan ada hubungan antara usia kehamilan dengan kejadian anemia pada ibu hamil di Puskesmas Bukit Sangkal Palembang tahun 2019 terbukti secara statistik.

\section{Hubungan Antara Paritas Dengan Kejadian Anemia Pada Ibu Hamil}

Tabel 6.

Hubungan Antara Paritas Dengan Kejadian Anemia Pada Ibu Hamil Di Puskesmas Bukit Sangkal Palembang Tahun 2019

\begin{tabular}{|c|c|c|c|c|c|c|c|c|c|}
\hline \multirow[t]{3}{*}{ No } & \multirow[t]{3}{*}{ Paritas } & \multicolumn{4}{|c|}{$\begin{array}{c}\text { Kejadian Anemia Pada } \\
\text { Ibu Hamil }\end{array}$} & \multicolumn{2}{|c|}{ Jumlah } & \multirow[t]{3}{*}{ p value } & \multirow{3}{*}{ OR } \\
\hline & & \multicolumn{2}{|c|}{ Ya } & \multicolumn{2}{|c|}{ Tidak } & \multirow[b]{2}{*}{$\mathbf{N}$} & \multirow[b]{2}{*}{$\%$} & & \\
\hline & & n & $\%$ & n & $\%$ & & & & \\
\hline 1. & Tinggi & 9 & 64,3 & 5 & 35,7 & 14 & 100 & \multirow{3}{*}{0,030} & \multirow{3}{*}{7,800} \\
\hline 2. & Rendah & 3 & 18,8 & 13 & 81,3 & 16 & 100 & & \\
\hline & Jumlah & 12 & & 18 & & 30 & & & \\
\hline
\end{tabular}

Berdasarkan tabel 6. diatas dapat dilihat bahwa dari 14 responden yang memiliki paritas tinggi sebagian besar mengalami kejadian anemia sebanyak 9 responden $(64,3 \%)$, sedangkan dari 16 responden yang memiliki paritas rendah sebagian besar tidak mengalami anemia sebanyak 13 responden $(81,3 \%)$

Dari hasil uji Chi-Square didapatkan nilai $p$ value $0,030<\alpha(0,05)$ hal ini menunjukkan ada hubungan antara paritas ibu dengan kejadian anemia pada ibu hamil di Puskesmas Bukit Sangkal Palembang tahun 2019. Sedangkan nilai $\mathrm{OR}=7,8$ hal ini menunjukkan bahwa ibu hamil yang memiliki paritas tinggi berpeluang mengalami kejadian anemia sebesar 7,8 kali dibandingkan dengan ibu hamil yang memiliki paritas rendah.

Sehingga hipotesa awal yang menyatakan ada hubungan antara paritas dengan kejadian anemia pada ibu hamil di Puskesmas Bukit 
Sangkal Palembang tahun 2019 terbukti secara

statistik.

\section{Hubungan Antara Jarak Kehamilan Dengan Kejadian Anemia Pada Ibu Hamil}

Tabel 7.

Hubungan Antara Jarak Kehamilan Dengan Kejadian Anemia Pada Ibu Hamil Di Puskesmas Bukit SangkalPalembang Tahun 2019

\begin{tabular}{|c|c|c|c|c|c|c|c|c|c|}
\hline \multirow[t]{3}{*}{ No } & \multirow[t]{3}{*}{ Jarak Kehamilan } & \multicolumn{4}{|c|}{$\begin{array}{l}\text { Kejadian Anemia Pada Ibu } \\
\text { Hamil }\end{array}$} & \multicolumn{2}{|c|}{ Jumlah } & \multirow[t]{3}{*}{$p$ value } & \multirow{3}{*}{ OR } \\
\hline & & \multicolumn{2}{|c|}{ Ya } & \multicolumn{2}{|c|}{ Tidak } & \multirow[b]{2}{*}{$\mathbf{N}$} & \multirow[b]{2}{*}{$\%$} & & \\
\hline & & $\mathbf{n}$ & $\%$ & $\mathbf{n}$ & $\%$ & & & & \\
\hline 1. & Tinggi & 8 & 72,7 & 3 & 27,3 & 11 & 100 & \multirow{3}{*}{0,009} & \multirow{3}{*}{10,000} \\
\hline 2. & Rendah & 4 & 21,1 & 15 & 78,9 & 19 & 100 & & \\
\hline & Jumlah & 12 & & 18 & & 30 & & & \\
\hline
\end{tabular}

Berdasarkan tabel 7. diatas dapat dilihat bahwa dari 11 responden yang memiliki jarak kehamilan tinggi sebagian besar mengalami kejadian anemia sebanyak 8 responden $(72,7 \%)$, sedangkan dari 19 responden yang memiliki jarak kehamilan rendah sebagian besar tidak mengalami anemia sebanyak 15 responden $(78,9 \%)$

Dari hasil uji Chi-Square didapatkan nilai $p$ value $0,009<\alpha(0,05)$ hal ini menunjukkan ada hubungan antara jarak kehamilan dengan kejadian anemia pada ibu hamil di Puskesmas Bukit Sangkal Palembang tahun 2019. Sedangkan nilai $\mathrm{OR}=10$ hal ini menunjukkan bahwa ibu hamil yang memiliki jarak kehamilan tinggi berpeluang mengalami kejadian anemia sebesar 10 kali dibandingkan dengan ibu hamil yang memiliki jarak kehamilan rendah.

Sehingga hipotesa awal yang menyatakan ada hubungan antara jarak kehamilan dengan kejadian anemia pada ibu hamil di Puskesmas Bukit Sangkal Palembang tahun 2019 terbukti secara statistik.

\section{Pembahasan}

Penelitian ini dilakukan di Puskesmas Bukit Sangkal Palembang pada tanggal 02-27 April 2019. Populasi yang diambil adalah semua ibu hamil trimester II dan trimester III yang memeriksakan kehamilannya di Puskesmas Bukit Sangkal Palembang pada saat dilakukan penelitian sebanyak 30 responden.Pengambilan sampel pada penelitian ini dilakukan dengan cara non probability sampling menggunakan metode accidental sampling.Teknik pengumpulan data pada penelitian ini menggunakan lembar observasi sebagai panduan mengambil data usia kehamilan, paritas dan jarak kehamilan pada saat memeriksakan kehamilannya serta mengukur kadar hemoglobin $\mathrm{Hb}$ ) dengan menggunakan $\mathrm{Hb}$ digital kemudian mencatat hasil pengukuran tersebut kedalam tabel observasi.

Kejadian Anemia Pada Ibu Hamil

Berdasarkan hasil analisis univariat diketahui bahwa distribusi frekuensi responden sebagian besar tidak mengalami anemia sebanyak 18 responden $(60 \%)$ dan hanya 12 responden $(40 \%)$ yang mengalami anemia.

Hasil penelitian ini sejalan dengan penelitian yang dilakukan Astriana (2017) yang berjudul kejadian anemia pada ibu hamil ditinjau dari paritas dan usia di Wilayah Kerja UPTD Puskesmas Tanjung Agung Kabupaten OKU. Hasil penelitian menunjukkan bahwa dari 277 responden yang mengalami kejadian anemia pada ibu hamil sebanyak 118 responden $(42,6 \%)$ dan sisanya 159 responden $(57,4 \%)$ yang tidak mengalami kejadian anemia pada ibu hamil.

Hasil penelitian ini sesuai dengan penelitian Puspitasari (2013), pada wanita hamil, anemia meningkatkan frekuensi terjadinya komplikasi pada kehamilan persalinan, resiko kematian maternal, prematuritas, BBLR, dan kematian perinatal. Disamping itu, perdarahan antepartum dan post partum lebih sering dijumpai pada wanita yang anemis dan lebih 
sering berakibat fatal. Sebab wanita yang anemis tidak dapat mentolerir kehilangan darah.

Anemia didefinisikan sebagai kondisi ibu dengan kadar hemoglobin $(\mathrm{Hb})<11$ gr\% pada trimester 1dan III sedangkan pada trimester II kadar hemoglobin <10,5 gr\%. Anemia kehamilan disebut "potentional danger to mother and child" ( potensi membahayakan ibu dan anak ), karena itulah anemia memerlukan perhatian serius dari semua pihak yang terkait dalam pelayanan kesehatan (Manuaba,2010; Bobak dalam Yanti, dkk.,2015)

Menurut Proverawati (2011) anemia merupakan suatu kumpulan gejala yang disebabkan oleh bermacam-macam penyebab.Terjadinya anemia karena adanya beberapa faktor yang saling berkaitan. Pada dasarnya anemia disebabkan oleh karena gangguan pembentukan eritrosit oleh sumsum tulang belakang, kehilangan darah(pendarahan), dan proses penghancuran erirosit dalam tubuh sebelum waktunya (hemolisis), faktor nutrisi, infeksi, dan pengaruh genetik. Penyebab anemiaantara lain pendarahan, misalnya ulkus, gastritis, tumor saluran pencernaan, malabsorpsi, kecelakaan yang mengakibatkan kehilangan banyak darah, malabsorpsi besi, dan menoragia (menstruasi berlebihan), defisiensi besi, asam folat, infeksi HIV, gangguan struktur hemoglobin seperti thalassemia

Menurut Huang (2015), menjelaskan bahwa banyak faktor yang mempengaruhi terjadinya anemia kehamilan di antaranya umur kehamilan, pendidikan ibu, pendapatan keluarga, jarak kehamilan, paritas, konsumsi tablet tambah darah (TTD), dan riwayat penyakit.Anemia di trimester (TM) I dan II tidak berhubungan dengan kejadian BBLR dan lahir preterm, sedangkan anemia di TM III mempunyai pengaruh terhadap kejadian BBLR dan lahir preterm.

Berdasarkan hasil penelitian dan pembahasan diatas peneliti berasumsi bahwa responden yang mengalami anemia lebih sedikit dibandingkan dengan responden yang tidak anemia. Hal ini disebabkan karena sebagian besar responden yang melakukan ante natal care (ANC) teratur setiap bulannya, dan teratur mengkonsumsi makanan kaya protein, Zat besi dan asam folat sehingga tidak terjadi anemia.

\section{Hubungan Antara Usia Kehamilan dengan Kejadian Anemia Pada Ibu Hamil}

Berdasarkan hasil analisis univariat diketahui bahwa distribusi frekuensi sebagian besar responden hamil trimester III sebanyak 16 responden $(53,3 \%)$ dan hanya 14 responden $(46,7 \%)$ yang hamil trimester II.

Berdasarkan hasil analisis bivariat dapat dilihat bahwa dari 16 responden usia kehamilan 28-40 minggu sebagian besar mengalami kejadian anemia sebanyak 10 responden $(62,5 \%)$, sedangkan dari 14 responden usia kehamilan 13-27 minggu sebagian besar tidak mengalami anemia sebanyak 12 responden $(85,7 \%)$

Dari hasil uji Chi-Square didapatkan nilai $p$ value $0,021<\alpha(0,05)$ hal ini menunjukkan ada hubungan antara usia kehamilan dengan kejadian anemia pada ibu hamil di Puskesmas Bukit Sangkal Palembang tahun 2019. Sedangkan nilai OR $=10$ hal ini menunjukkan bahwa ibu hamil dengan usia kehamilan trimester III berpeluang mengalami kejadian anemia sebesar 10 kali dibandingkan dengan ibu hamil usia kehamilan trimester II. Sehingga hipotesa awal yang menyatakan ada hubungan antara usia kehamilan dengan kejadian anemia pada ibu hamil di Puskesmas Bukit Sangkal Palembang tahun 2019 terbukti secara statistik.

Hasil penelitian ini sejalan dengan hasil penelitian Hidayati (2018) yang berjudul hubungan jumlah paritas dan umur kehamilan dengan kejadian anemia ibu hamil. Hasil penelitian menunjukkan bahwa dari $100 \%$ responden yang masuk pada trismester ke satu $58,1 \%$ responden terkena anemia, dan dari $100 \%$ responden yang masuk pada trismester ke dua $43,8 \%$ responden terkena anemia. Hasil uji korelasi rank spearman menunjukkan bahwa ada hubungan antara umur kehamilan dengan kejadian anemia pada ibu hamil ( $\mathrm{p}$ value = 0,012) di wilayah Puskesmas Kintamani 1 Kecamatan Kintamani Kabupaten Bangli Provinsi Bali

Hal ini sesuai dengan pernyataan 
Hidayati (2018), yang menyatakan bahwa kebutuhan zat besi selama kehamilan menunjukkan peningkatan seiring bertambahnya umur kehamilan.Kebutuhan zat besi pada 18 minggu pertama kehamilan tidak menunjukkan peningkatan sehingga masukan dari makanan sebesar 11-13 mg/hari telah mampu mencukupi kebutuhan tersebut. Setelah 20 minggu, massa eritrosit ibu mulai bertambah dan fetus membutuhkan lebih banyak zat besi. Kebutuhan zat besi menunjukkan peningkatan tajam selama trimester dua dan khususnya trimester tiga.Morisson and Marc (2011) mengemukakan bahwa kebutuhan harian zat besi di trimester tiga 4,1 mg lebih tinggi dibandingkan kebutuhan sebelum hamil yaitu sebesar 5,6 mg/hari $(3,54-$ $8,80 \mathrm{mg} /$ hari).

Selain itu Hidayati (2018) juga menambahkan bahwa pemeriksaan hemoglobin untuk mendeteksi anemia dilakukan di triwulan pertama umur kehamilan (6 bulan). Pada pemeriksaan dan pengawasan hemoglobin dapat dilakukan dengan menggunakan metode Sahli, dilakukan minimal 2 kali selama kehamilan yaitu trimester I dan III. Masa kehamilan terutama trimester III merupakan masa kritis dimana kebutuhan akan zat gizi meningkat. Jika zat besi dalam darah kurang maka kadar hemoglobin akan menurun yang mengakibatkan gangguan dan pertumbuhan janin. Beberapa penelitian menyatakan bahwa kadar $\mathrm{Hb}$ ibu hamil trimester akhir dan tingginya angka anemia pada trimester III dapat mempengaruhi berat badan lahir. Kebutuhan zat besi ibu hamil meningkat pada kehamilan trimester II dan III. Pada masa tersebut kebutuhan zat besi tidak dapat diandalkan dari menu harian saja. Walaupun menu hariannya mengandung zat besi yang cukup, ibu hamil tetap perlu tambahan tablet besi atau vitamin yang mengandung zat besi. Zat besi bukan hanya penting untuk memelihara kehamilan. Ibu hamil yang kekurangan zat besi dapat menimbulkan perdarahan setelah melahirkan, bahkan infeksi, kematian janin intra uteri, cacat bawaan dan abortus.

Hal yang sama diungkapkan Hidayati (2018), bahwa peningkatan kebutuhan zat besi pada ibu hamil tersebut tidak dapat dipenuhi hanya dari makanan, bahkan makanan yang telah mengalami fortifikasi zat besi juga tidak mampu memenuhi kebutuhan ini. Oleh karenanya pemenuhan zat besi saat hamil juga tergantung pada dua faktor yaitu cadangan zat besi sebelum hamil dan suplemen zat besi selama kehamilan. Anemia pada kehamilan di TM III dihubungan dengan peningkatan umur kehamilan yang menyebabkan ibu semakin lemah dan zat besi di dalam darah dibagi untuk pertumbuhan fetus di dalam rahim sehingga mengurangi kapasitas pengikatan zat besi di dalam darah ibu. Ibu hamil harus mengonsumsi makanan yang bergizi diimbangi dengan suplementasi TTD untuk mengompensasi hemodilusi yang terjadi.

Berdasarkan hasil penelitian dan pembahasan diatas peneliti berasumsi bahwa ibu hamil yang umur kehamilannya sudah memasuki trimester III dapat beresiko terjadinya anemia pada kehamilan. Hal ini disebabkan karena pada trimester III, kebutuhan zat besi dan asam folat, vitamin ibu akan semakin meningkat karena untuk mencukupi kebutuhan sel darah janin yang diperlukan untuk pertumbuhannya, sehingga jika kebutuhan zat besi, asam folat dan vitamin pada trimester III tidak terpenuhi dapat menyebabkan resiko terjadinya anemia pada kehamilan.

\section{Hubungan Antara Paritas Ibu dengan Kejadian Anemia Pada Ibu Hamil}

Dari tabel analisis univariat diketahui bahwa distribusi frekuensi sebagian besar responden memiliki paritas resiko rendah sebanyak 16 responden (53,3\%)dan hanya 14 responden $(46,7 \%)$ yang memiliki paritas resiko tinggi.

Berdasarkan analisis bivariat diketahui dapat dilihat bahwa dari 14 responden yang memiliki paritas tinggi sebagian besar mengalami kejadian anemia sebanyak 9 responden $(64,3 \%)$, sedangkan dari 16 responden yang memiliki paritas rendah sebagian besar tidak mengalami anemia sebanyak 13 responden $(81,3 \%)$

Dari hasil uji Chi-Square didapatkan nilai $p$ value $0,030<\alpha(0,05)$ hal ini menunjukkan ada hubungan antara paritas ibu dengan kejadian anemia pada ibu hamil di 
Puskesmas Bukit Sangkal Palembang tahun 2019. Sedangkan nilai OR $=7,8$ hal ini menunjukkan bahwa ibu hamil yang memiliki paritas tinggi berpeluang mengalami kejadian anemia sebesar 7,8 kali dibandingkan dengan ibu hamil yang memiliki paritas rendah.Sehingga hipotesa awal yang menyatakan ada hubungan antara paritas dengan kejadian anemia pada ibu hamil di Puskesmas Bukit Sangkal Palembang tahun 2019 terbukti secara statistik.

Hasil penelitian ini sejalan dengan penelitian Abrori (2016) yang berjudul faktor anemia ibu hamil di Puskesmas Putussibau Selatan. Hasil penelitian didapatkan distribusi RespondenBerdasarkan Jarak Kehamilan, Umur, Paritasdan Status Gizi Pada Ibu Hamil di Puskesmas PutussibauSelatan, dilihat bahwa berdasarkan analisis bahwavariabel paritas tidak berisiko $\leq 4$ orang lebih banyaksebesar $(60,0 \%)$, hasil uji statistik didapatkan adanya hubungan yang bermaknaparitas dengan kejadiananemia pada ibu hamil ( $p$ value $=0,032$ )di Puskesmas Putussibau Selatan.

Penelitian serupa dilakukan Desfauza (2016) yang berjudul umur dan paritas ibu berhubungan dengan anemia pada ibu hamil di Klinik Bersalin Sumiariani Kec. Medan Johor. Hasil analisa dengan uji Chi-Square. Didapat nilai $\mathrm{p}$ value $=0,002<0,05$ memperlihatkan adanya hubungan paritas ibu dengan terjadinya anemia pada ibu hamil.

Menurut Astriana (2017), paritas merupakan salah satu faktor penting dalam kejadian anemia zat besi pada ibu hamil. Wanita yang sering mengalami kehamilan dan melahirkan makin anemia karena banyak kehilangan zat besi, hal ini disebabkan selama kehamilan wanita menggunakan cadangan besi yang ada di dalam tubuhnya.

Menurut Wiknjosastro (2002), Paritas 1 dan paritas tinggi (lebih dari 5) mempunyai angka kematian maternal lebih tinggi. Lebih tinggi paritas, lebih tinggi kematian maternal. Risiko pada paritas 1 dapat ditangani dengan asuhan obstetrik lebih baik, sedangkan resiko pada paritas tinggi dapat dikurangi atau dicegah dengan menjadi akseptor Keluarga Berencana.
Sebagian kehamilan pada paritas tinggi adalah tidak direncanakan.

Menurut Wahyu (2015), yang menyatakan bahwa paritas 2-3 merupakan paritas paling aman ditinjau dari sudut kematian maternal. Paritas 1 dan paritas tinggi (lebih dari 3) mempunyai angka kematian maternal lebih tinggi. Lebih tinggi paritas, lebih tinggi kematian maternal. Resiko pada paritas 1 dapat ditangani dengan asuhan obstetrik lebih baik, sedangkan resiko pada paritas tinggi dapat dikurangi ataudicegah dengan keluarga berencana. Sebagian kehamilan pada paritas tinggi adalah tidak direncanakan. Paritas mempengaruhi kejadian anemia pada kehamilan, semakin sering seorang wanita hamil dan melahirkan maka risiko mengalami anemia semakin besar karena kehamilan menguras cadangan zat besi dalam tubuh.

Menurut teori Widatiningsih, (2016).Anemia berdampak buruk terhadap kehamilan maupun persalinan sehingga perlu dideteksi lebih dini agar dapat segera dicari penyebabnya untuk diatasi. Peggolongan anemia dalam kehamilan: anemia ringan $(\mathrm{Hb}<11$ hingga $9 \mathrm{~g} \%$ ), anemia sedang ( $\mathrm{Hb}<9$ sampai 8 $\mathrm{g} \%)$, anemia bera ( $\mathrm{Hb}<8 \mathrm{gr} \%)$. Anemia yang disebabkan oleh kondisi apapun (termasuk talasemia, seckle cell, maupun defisiensi) mengakibatkan penuruan kapasitas pengikatan oksigen oleh darah sehingga jantung berusaha mengkompensasinya dengan meningkatkan COP yang mengakibatkan peningkatan beban kerja jantung. Jika anemia menyertai kondisi lain seperti preeklampsia maka dapat berakibat gagal jantung.

Menurut Manuaba (2010), wanita yang sering mengalami kehamilan dan melahirkan makin anemia karena banyak kehilangan zat besi, hal ini disebabkan selama kehamilan wanita menggunakan cadangan besi yang ada di dalam tubuhnya.

Berdasarkan hasil penelitian dan pembahasan diatas peneliti berpendapat bahwa paritas ibu resiko tinggi dapat mempengaruhi kejadian anemia pada ibu hamil trimester III. Hal ini karena ibu yang memiliki paritas 1 mempunyai kekurangsiapan dalam menghadapi persalinan disebabkan ibu belum pernah 
melahirkan seperti kurang mempersiapkan kondisi fisik maupun psikologis menjelang persalinan sehingga ibu rentan mengalami berbagai komplikasi seperti anemia dan perdarahan. Sedangkan ibu yang memiliki paritas > 3 disebabkan karena otot-otot pada daerah organ reproduksinya sudah mengalami kekendoran terutama pada dinding perut dan dinding rahim sehingga dari keadaan tersebut maka akan mudah menimbulkan berbagai macam komplikasi yang berakibat terjadinya anemia dan perdarahan.

\section{Antara Jarak Kehamilan dengan Kejadian Anemia Pada Ibu Hamil}

Berdasarkan hasil analisis univariat diketahui distribusi frekuensi sebagian besar responden memiliki jarak kehamilan resiko rendah sebanyak 19 responden $(63,3 \%)$ dan hanya 11 responden $(36,7 \%)$ yang memiliki jarak kehamilan resiko tinggi.

Berdasarkan hasil analisisi bivariat diketahui dari 11 responden yang memiliki jarak kehamilan tinggi sebagian besar mengalami kejadian anemia sebanyak 8 responden $(72,7 \%)$, sedangkan dari 19 responden yang memiliki jarak kehamilan rendah sebagian besar tidak mengalami anemia sebanyak 15 responden $(78,9 \%)$.

Dari hasil uji Chi-Square didapatkan nilai $p$ value $0,009<\alpha(0,05)$ hal ini menunjukkan ada hubungan antara jarak kehamilan dengan kejadian anemia pada ibu hamil di Puskesmas Bukit Sangkal Palembang tahun 2019. Sedangkan nilai $O R=10$ hal ini menunjukkan bahwa ibu hamil yang memiliki jarak kehamilan tinggi berpeluang mengalami kejadian anemia sebesar 10 kali dibandingkan dengan ibu hamil yang memiliki jarak kehamilan rendah. Sehingga hipotesa awal yang menyatakan ada hubungan antara jarak kehamilan dengan kejadian anemia pada ibu hamil di Puskesmas Bukit Sangkal Palembang tahun 2019 terbukti secara statistik.

Hasil penelitian ini sejalan dengan penelitian Wahyu (2015), yang berjudul faktorfaktor yang berhubungan dengan kejadian anemia pada ibu hamil di Puskesmas Godean II Sleman Yogyakarta. Hasil penelitian didapatkan bahwa persentase tertinggi jarak kehamilan resiko tinggi sebanyak 48 orang $(53,3 \%)$, kelompok kontrol dan kelompok kasus masingmasing sebanyak 45 orang (50\%). Hasil uji statistik menggunakan Chi Square didapatkan nilai p $0,035<\alpha(0,05)$ yang berarti ada hubungan jarak kehamilan dengan kejadian anemia pada ibu hamil di Puskesmas Godean II Sleman Yogkarta.

Hal ini sesuai dengan pernyataan Abrori (2016), yang menyatakan bahwa jarak antara persalinan terakhir dengan kehamilan berikutnya sebaiknya antara dua sampai lima tahun, jarak yang terlalu dekat (kurang dari 2 tahun) berhubungan dengan meningkatnya resiko kejadian keguguran, bayi dengan berat badan lahir rendah (kurang dari 2.500 gram), kematian janin dan kematian bayi. Kehamilan yang terlalu dekat untuk seorang ibu dapat meningkatkan kejadian anemia karena status gizi ibu belum pulih, selain itu seorang ibu bisa mengalami infeksi, ketuban pecah dini dan pendarahan. Ibu dengan jarak kehamilan lebih dari 2 tahun seharusnya lebih tinggi di banding jarak kehamilan dekat untuk menciptakan keluarga bahagia karena dalam keluarga tersebut ibu dapat memberikan perhatian sesuai dengan anak pertama dan kehamilan keduanya.

Selain itu Abrori (2016), juga menambahkan bahwa salah satu penyebab anemia adalah jarak kehamilan yang pendek $<2$ tahun, karena memerlukan tambahan zat besi untuk meningkatkan jumlah sel darah merah dan membentuk sel darah merah janin dan plasenta. Jika persediaan cadangan $\mathrm{Fe}$ minimal, maka setiap kehamilan akan menguras persediaan $\mathrm{Fe}$ dalam tubuh dan akhirnya menimbulkan anemia pada kehamilan berikutnya.

Menurut Abrori (2016), jarak kehamilan yang terlalu dekat menyebabkan terjadinya anemia, karena kondisi ibu masih belum pulih dan pemenuhan kebutuhan zat-zat gizi belum optimal, sudah harus memenuhi kebutuhan nutrisi janin yang dikandungnya. Perencanaan kehamilan atau persalinan sangat penting dilaksanakan pada setiap pasangan untuk menekan jarak kehamilan $\geq 2$ tahun dan kejadian anemia pada ibu hamil, dengan mengkonsumsi makanan kaya protein, zat besi dan asam folat. 
Berdasarkan hasil penelitian dan pembahasan diatas peneliti berasumsi bahwa jarak kehamilan yang terlalu dekat dapat beresiko terjadinya anemia pada ibu hamil. Hal ini dikarenakan kondisi organ-organ reproduksi ibu yang belum pulih sepenuhnya pasca melahirkan yang sebelumnya sehingga menyebabkan terjadinya peningkatan kebutuhan zat besi untuk meningkatkan jumlah sel darah merah dan membentuk sel darah merah janin dan plasenta sehingga dapat meningkatkan kejadian anemia pada kehamilan.

\section{KESIMPULAN}

Berdasarkan hasil penelitian yang telah dilakukan di Puskesmas Bukit Sangkal Palembang, dapat disimpulkan :

1. Distribusi frekuensi responden sebagian besar tidak mengalami anemia sebanyak 18 responden $(60 \%)$ dan hanya 12 responden (40\%) yang mengalami anemia.

2. Distribusi frekuensi sebagian besar responden hamil trimester III sebanyak 16 responden $(53,3 \%)$ dan hanya 14 responden $(46,7 \%)$ yang hamil trimester II.

3. Distribusi frekuensi sebagian besar responden memiliki paritas resiko rendah sebanyak 16 responden $(53,3 \%)$ dan hanya 14 responden $(46,7 \%)$ yang memiliki paritas resiko tinggi.

4. Distribusi frekuensi sebagian besar responden memiliki jarak kehamilan resiko rendah sebanyak 19 responden $(63,3 \%)$ dan hanya 11 responden $(36,7 \%)$ yang memiliki jarak kehamilan resiko tinggi.

5. Ada hubungan antara usia kehamilan dengan kejadian anemia pada ibu hamil di Puskesmas Bukit Sangkal Palembang tahun 2019 dengan nilai $p$ value $=0,021$ sedangkan nilai $\mathrm{OR}=10$.

6. Ada hubungan antara paritas dengan kejadian anemia pada ibu hamil di Puskesmas Bukit Sangkal Palembang tahun 2019 dengan nilai $\mathrm{p}$ value $=0,030$ sedangkan nilai $\mathrm{OR}=7,8$.

7. Ada hubungan antara jarak kehamilan dengan kejadian anemia pada ibu hamil di Puskesmas Bukit Sangkal Palembang tahun
2019 dengan nilai $\mathrm{p}$ value $=0,009$ sedangkan nilai $\mathrm{OR}=10$.

\section{SARAN}

1. Bagi Puskesmas Bukit Sangkal Palembang

Diharapkan petugas kesehatan khususnya di Puskesmas Bukit Sangkal Palembang agar dapat meningkatkan penyuluhan dengan mengembangkan program KIE dan Konseling mengenai usia ibu danparitas ibu yang merupakan faktor resiko tinggi kejadian anemia pada ibu hamil khusnya ibu hamil trimester III.

\section{Bagi STIKES Mitra Adiguna Palembang}

Diharapkan kepada institusi

pendidikan STIKES Mitra Adiguna Palembang Agar dapat melengkapi bahanbahan bacaan kepustakaan khususnya tentang anemia agar dapat menambah pengetahuan dan wawasan mahasiswi kebidanan yang akan meneliti tentang anemia pada ibu hamil.

\section{Bagi Peneliti yang Akan Datang}

Agar meneliti variabel-variabel yang lain dengan metode yang berbeda serta sampelyang lebih banyak mengenai kejadian anemia pada ibu hamil agar didapatkan hasil penelitian yang lebih baik dan akurat.

\section{DAFTAR PUSTAKA}

Abrori. 2016.Faktor Anemia Ibu HamilDi Puskesmas Putussibau Selatan. Fakultas Ilmu Kesehatan, Universitas Muhammadiyah Pontianak

Alene KA, Abdulahi MD (2014). Prevalence of Anemia and Associated Factors among Pregnant Women in an Urban Area of Easthern Ethiopia. Hindawi Publishing Corporation. http://dx.d-oi.org. Diakses5 Januari 2016.

Al-Farsi YM, Daniel RB, Martha MW, Howard JC, MohammedAA, Henk CW(2011). Effect of High Parity on Occur-rence Of Anemia In Pregnancy: A Cohort Study. BMC Pregnancy and Childbirth. 2011(11):1-7.www.biomed-central.com. Diakses1 September 2016. 
Almatsier, S., 2009. Prinsip Dasar Ilmu Gizi, Edisi ke-8. Gramedia Pustaka Utama. Jakarta.

Ani, LS. 2016. Buku Saku Anemia Defisiensi Besi. Jakarta: EGC Marmi, 2013. Gizi Dalam Kesehatan Reproduksi. Yogyakarta: Pustaka Pelajar.

Bakta, M. 2007. Hematologi Klinik Ringkas. EGC.Jakarta:26-45.

Desfauza. 2016. Umur dan paritas ibu berhubungan dengan anemia pada ibu hamil di Klinik Bersalin Sumiariani Kec. Medan Johor

Hidayati. 2018. Hubungan Jumlah Paritas Dan Umur Kehamilan Dengan Kejadian Anemia Ibu Hamil

Huang LL, Gowreesunkur P, Su MW, Lin LZ, Hui $\mathrm{T}(2015)$. The Influence of Irondeficiency Anemia during the Pregnancy on Preterm Birth and Birth Weight in South China. Journal of Food and Nutrition Research 3(9):570-574.

Kemenkes RI. 2017. Survey Demografi Dan Kesehatan IndonesiaTahun 2012. Jakarta. Badan Pusat Statistik Indonesia.

Manuaba,IAC.,IBagus, danIBGde.2010.IlmuKebi danan,PenyakitKandungandanKBuntuk PendidikanBidan.Edisikedua.Jakarta:EG C.

Masukume G, Ali SK, Louise CK, Philip NB, and GillN(2015). Risk Factors and Birth Outcomes of Anaemia in Early Pregnancy in a Nulliparous Cohort. PLOSONE 10(4): e0122729.

Mubarak, WI. (2007). Promosi Kesehatan untuk Kebidanan. Jakarta: Salemba Medika

Notoatmodjo, S. 2012. Metodologi Penelitian

Kesehatan. Jakarta. Rineka Cipta.

Proverawati, A., dan Wati, EK., 2011. Ilmu Gizi Untuk Keperawatan dan GiziKesehatan. Yogyakarta: Nuha medika.

Prawirohardjo, S. (2007). Ilmu Kebidanan, Edisi 4: cetakan 3. Jakarta: Yayasan BinaPustaka Saswono Prawirohardjo.

Prawirohardjo, S. (2013). Patologi Kehamilan. Jl. Wonosari km, 6 Demblaksari Baturetno Banguntapan Bantul Yogyakatra : Pustaka Baru Press
Riskesdas. (2013). Riset Kesehatan Dasar. Jakarta : Badan Penelitian dan Pengembangan Kesehatan Kementerian Kesehatan RI

Rohani. 2017. Dikat Asuhan Kebidanan Pada Kehamilan. Palembang : Kampus : Palembang-Sumtera Selatan

Soebroto I. Cara Mudah Mengatasi Problem Anemia. Yogakarta: Bangkit; 2009.

Siriwong O(2012). Anemia in Pregnant Women Attending the Antenatal Care Clinic, Mae Sot Hospital. Thai Journal of Obstetrics and Gynaecology October (20): 186-190.

Sulistyawati A.2009.Buku ajar asuhan kebidanan pada ibu nifas. Yogyakarta: Andi Offset

Sugiyono. (2016). Metode Penelitian Manajemen. Bandung: CV Alfabeta.

Tarwoto N, Wasnidar. Buku Saku Anemia Pada Ibu Hamil Konsep dan Penatalaksanaan. Jakarta: Trans Info Media; 2007.

Varney, J. M. Kriebs, C.L. Gegor. 2007. Buku Ajar Asuhan Kebidanan Edisi 4 Volume1.Jakarta:EGC.

Wahyu, Tri Wiwin. 2015. Hubungan paritas dengan kejadian anemia pada ibu hamil di Puskesmas Godean II Sleman Yogyakarta. Jurnal Fakultas Ilmu Kesehatan Universitas 'Aisyiyah Yogyakarta.

Widatiningsih. 2016. Praktik terbaik asuhan kehamilan. Jakarta : Trans Medika

Word Health Organization (WHO). 2015. The Global Prevalence of Anemia.ISBN 9789241564960.

Word Health Organization (WHO ) et all. 2013 Buku Saku Pelayanan Kesehatan Ibu di Fasiltas Kesehatan Dasar dan Rujukan Jakarta : Uncef et,all

Wiknjosastro. 2002. Ilmu Kebidanan. Jakarta : PT. Sarwono Prawiroharjo 